How to cite: Demirci, M., Uneș, F., Akoz, M.S. (2020) Laboratory Investigation of Cross-Shore Sandbar Beginning and Ending Depths. 2020 "Air and Water - Components of the Environment" Conference Proceedings, Cluj-Napoca, Romania, p. 1-10, DOI: 10.24193/AWC2020_01.

\title{
LABORATORY INVESTIGATION OF CROSS-SHORE SANDBAR BEGINNING AND ENDING DEPTHS
}

\author{
Mustafa DEMIRCI ${ }^{1}$, Fatih UNEȘ ${ }^{1}$, Mevlut Sami AKOZ \\ DOI: 10.24193/AWC2020_01
}

\begin{abstract}
In the coastal regions, cross shore sediment transport causes significant changes in coastal morphology. In the design of structures such as sea walls, spurs and breakwaters, it is of great importance to accurately determine the movement of sediment in the onshore-offshore direction in filling and erosion and preventing them. In this study, experimental studies on cross shore sediment transport have been carried out with an initial shore slope of $1 / 8,1 / 10$ and $1 / 15$. In the experiments carried out with regular waves having different deep-water wave steepness. The geometric properties of sandbar starting and ending depths formed under storm conditions for sediment average grain diameters $\mathrm{d}_{50}=0.25,0.32,0.45,0.62$ and $0.8 \mathrm{~mm}$ were investigated.
\end{abstract}

Keywords: cross shore sediment transport, bar beginning depth, bar ending depth

\section{INTRODUCTION}

Coastal engineering applications include problems encountered in practice such as design of coastal structures, prevention of coastal erosion, protection of ports against sandblasting and projecting of sea discharges. In order to solve such problems in a healthy way, sea floor movement mechanics must be understood correctly.

Optimum use of the shore, protection of the shore and so on. Coastal structures built for purposes generally sit on mobile floors. Cross shore sediment transport causes stability problems due to sandblasting in some coast and erosion in others, thus shortening the economic life of the structure and increasing repair costs. Therefore, one of the most important factors in the design of coastal structures is coastal profiles.

Sea floor profiles, where most of the wave energy is damped, can have different characteristics in time and under various wave conditions. Parameters such as wave conditions, base slope, material properties significantly affect the transport of sediment and consequently the change of base profiles.

The results of the previous studies on coastal profiles and bar parameters were examined. The most important of these are Larson and Kraus (1989), Kraus et al. (1991), Silvester and Hsu (1997), Hsu (1998), Türker (2002), Günaydın and Kabdaşlı

\footnotetext{
${ }^{1}$ Department of Civil Engineering, Iskenderun Technical University, mustafa.demirci@iste.edu.tr faith.unes@iste.edu.tr

${ }^{2}$ Department of Civil Engineering, Cukurova University, Turkey, msa@cu.edu.tr
} 
(2003 and 2005), Demirci (2006), Kömürcü et al. (2007), Demirci and Akoz (2012), Demirci and Akoz (2013), Demirci et al. (2014), Demirci et al. (2015) and Demirci et al. (2016), Çelikoğlu et al. (2004 and 2006), Tătui et al. (2016), Eichentopf et al (2018), Kankal et al. (2018).

As a result of the literature studies, it was found that the most important parameters affecting the erosion geometry in the shore profile were wave height $\left(\mathrm{H}_{0}\right)$, period $(\mathrm{T})$, base slope $(\mathrm{m})$ and base material diameter $\left(\mathrm{d}_{50}\right)$.

The aim of this study is to investigate the geometric properties of cross shore bar beginning and ending depths formed under storm conditions for sediment average grain diameters $\mathrm{d}_{50}=0.25,0.32,0.45,0.62$ and $0.8 \mathrm{~mm}$ were investigated.

\section{DATA AND METHODS}

64 experimental studies on the geometric properties of cross shore profiles under storm conditions were carried out in a $12 \mathrm{~m}$ long, $0.40 \mathrm{~m}$ wide and $0.60 \mathrm{~m}$ deep glass wall wave channel in the Civil Engineering Laboratory (Figure 1).

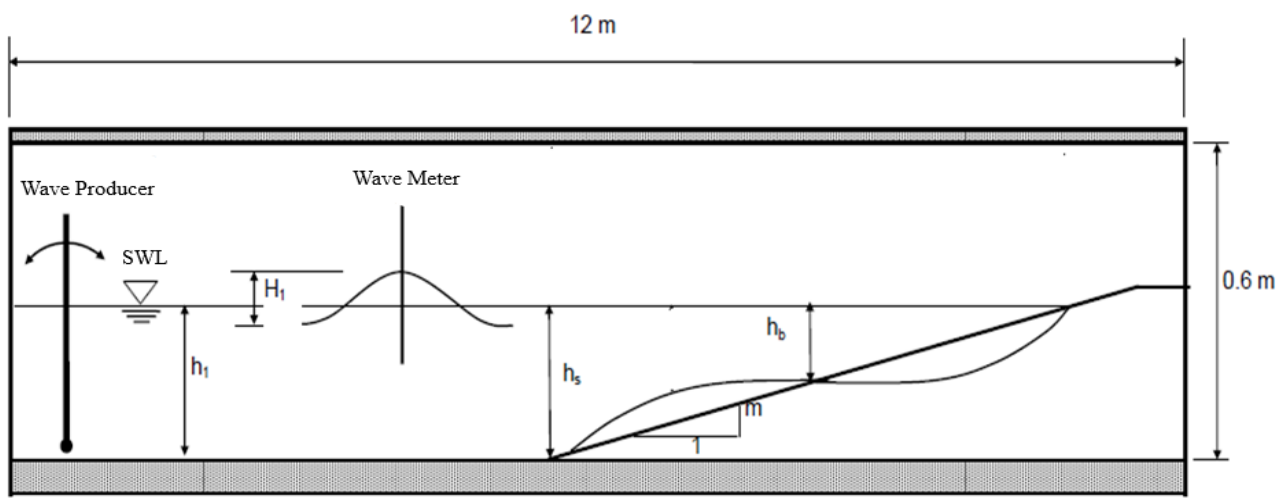

Fig. 1. Experimental setup

The wave channel has an inclined shore base at one end and a wave generator at the other end. The waves in the channel are generated with the help of the pedaltype wave generator.

The characteristics of the generated waves can be varied due to the adjustable speed of the electric motor rotating the pedal and the length of the arm to which the motor is connected to the pedal. In this way, regular waves with wave periods ranging from 0.47 to $0.76 \mathrm{~s}$ were generated.

The experiments were carried out on base slopes of $1 / 8,1 / 10,1 / 15$ placed in the wave channel. Five different average grain diameter sand material was used as coastal material. The average grain diameter of the sand material used in the experiments: $\mathrm{d}_{50}=0.25,0.32,0.45,0.62$ and $0.80 \mathrm{~mm}$. 


\section{RESULTS AND DISCUSSIONS}

\section{Relative Bar Beginning Depth $-\mathbf{h}_{b} / \mathbf{L}_{0}$}

The distance from the beginning point of the bar to the still water level $\left(\mathrm{h}_{\mathrm{b}}\right)$ is divided by the deep-water wavelength $\left(\mathrm{L}_{0}\right)$ to obtain the relative bar beginning depth.

Below are the variations of the initial depths of the dimensionless bar with respect to the deep-water wave steepness for the average grain diameters ranging from $1 / 8,1 / 10$ and $1 / 15$ slope and $\mathrm{d}_{50}=0.25$ to $0.80 \mathrm{~mm}$.

The change of the dimensionless distance of the bar starting point to the still water level was investigated for the $\mathrm{d}_{50}=0.25,0.32,0.45,0.62$ and $0.80 \mathrm{~mm}$ average grain diameter.

In figures $2-6$, this change is presented for different shore slopes of $1 / 8,1 / 10$ and $1 / 15$. It is seen from the figures that the dimensionless bar beginning depth increases with the increasing deep-water wave steepness for each three slopes.

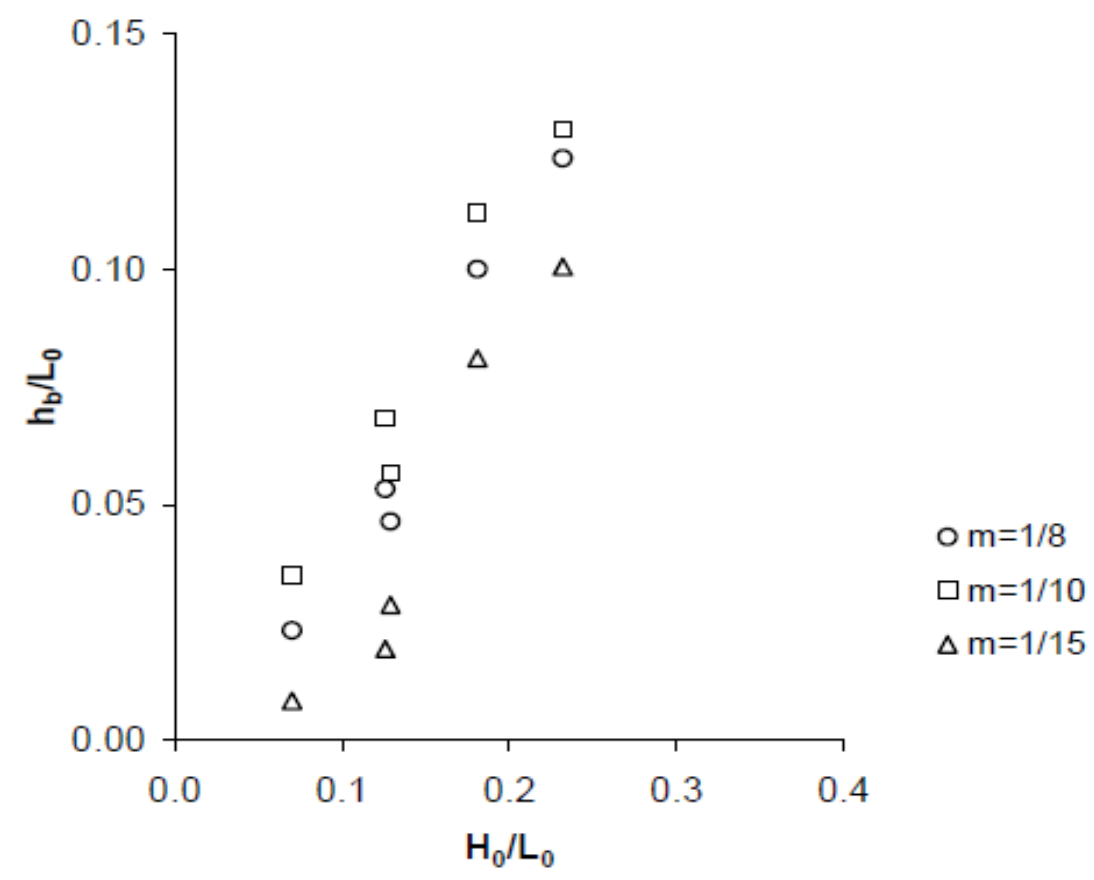

Fig. 2. Variation of Relative Bar Beginning Depth with the Wave Steepness for $d_{50}=0.25 \mathrm{~mm}$

The increase in the relative bar beginning with the increase in the deep-water wave steepness is observed for all grain diameters. 


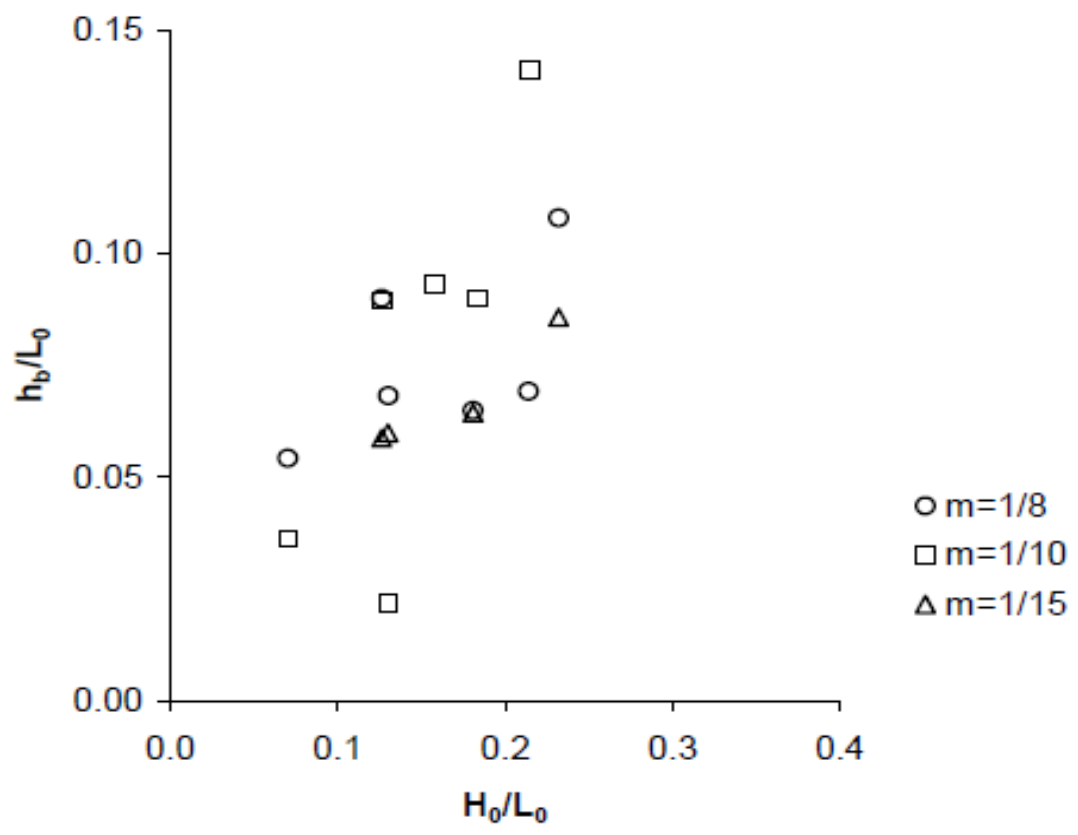

Fig. 3. Variation of Relative Bar Beginning Depth with the Wave Steepness for $d_{50}=0.32 \mathrm{~mm}$

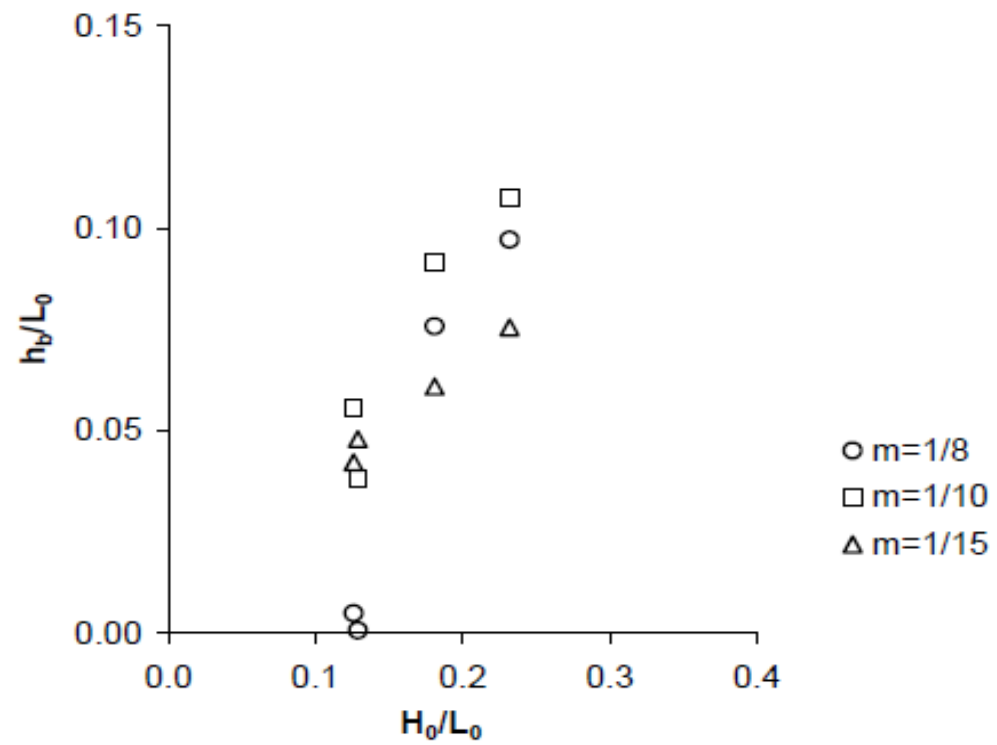

Fig. 4. Variation of Relative Bar Beginning Depth with the Wave Steepness for $d_{50}=0.45 \mathrm{~mm}$ 


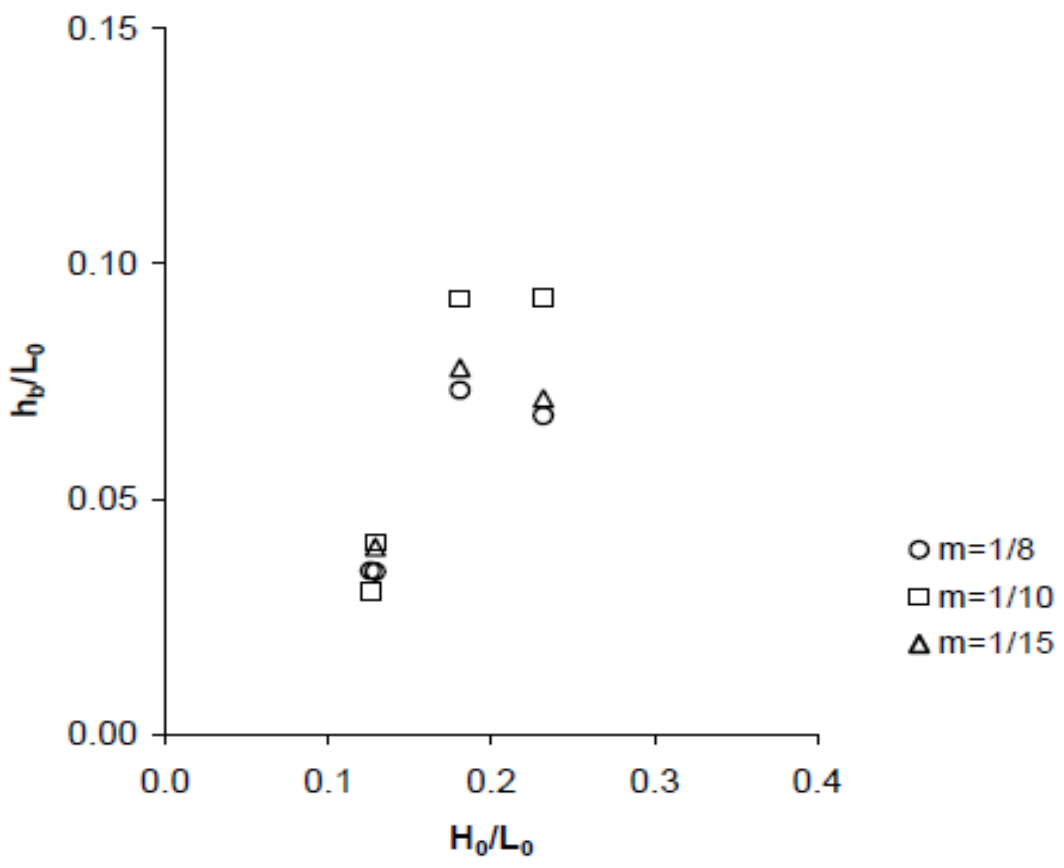

Fig. 5. Variation of Relative Bar Beginning Depth with the Wave Steepness for $d_{50}=0.62 \mathrm{~mm}$

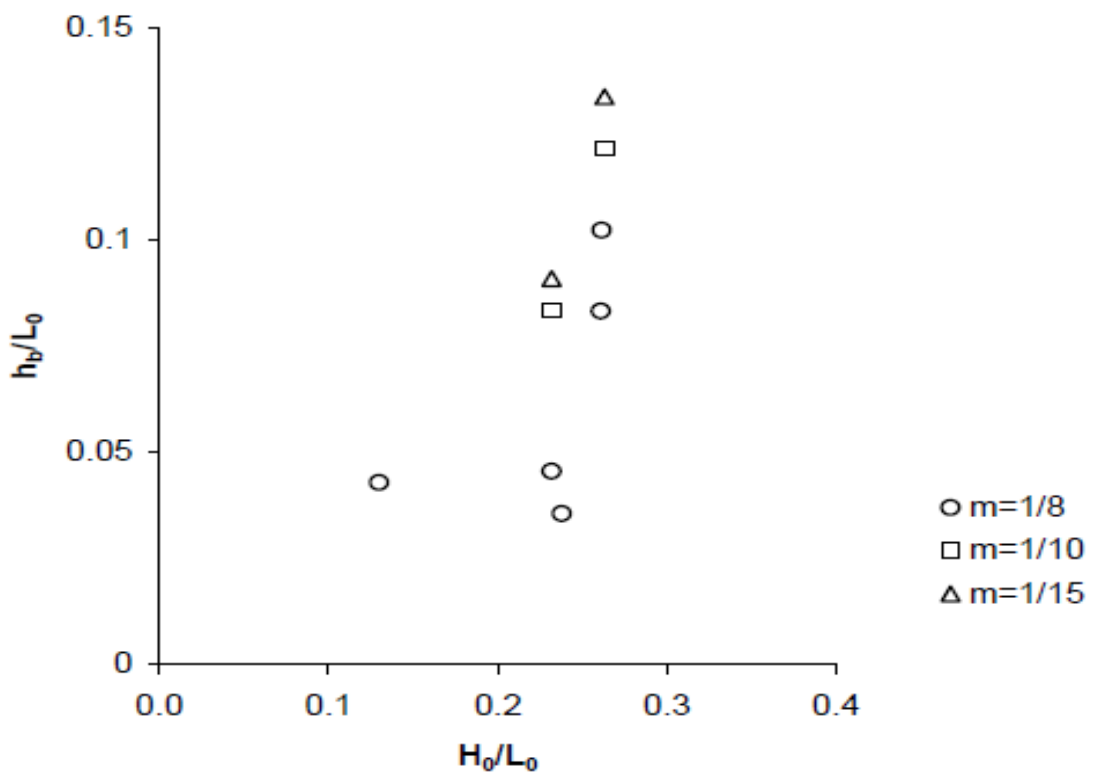

Fig. 6. Variation of Relative Bar Beginning Depth with the Wave Steepness for $d_{50}=0.80 \mathrm{~mm}$ 


\section{Relative Bar Ending Depth- hs / $\mathbf{L}_{0}$}

The distance of bar ending point to still water level $\left(\mathrm{h}_{\mathrm{s}}\right)$ is divided by deepwater wavelength $\left(\mathrm{L}_{0}\right)$, and relative bar ending depth $\left(\mathrm{hs} / \mathrm{L}_{0}\right)$ is obtained.

In the following, the variations of the relative bar ending depth with the deep-water wave steepness for different slope and average grain diameters are presented.

Variation of the relative bar ending depth with deep-water wave steepness was investigated for $\mathrm{d}_{50}=0.25,0.32,0.45,0.62$ and $0.80 \mathrm{~mm}$ average grain diameter.

They are presented for $1 / 8,1 / 10$ and $1 / 15$ coastal slopes in figures $7-11$.

As can be seen from the figures, with the increasing of the deep-water wave steepness, the relative ending depth of the bar increases. This is the case for all three slopes.

An increase in relative bar ending depths with increasing deep-water wave steepness is also present for all grain diameters studied in this experiment.

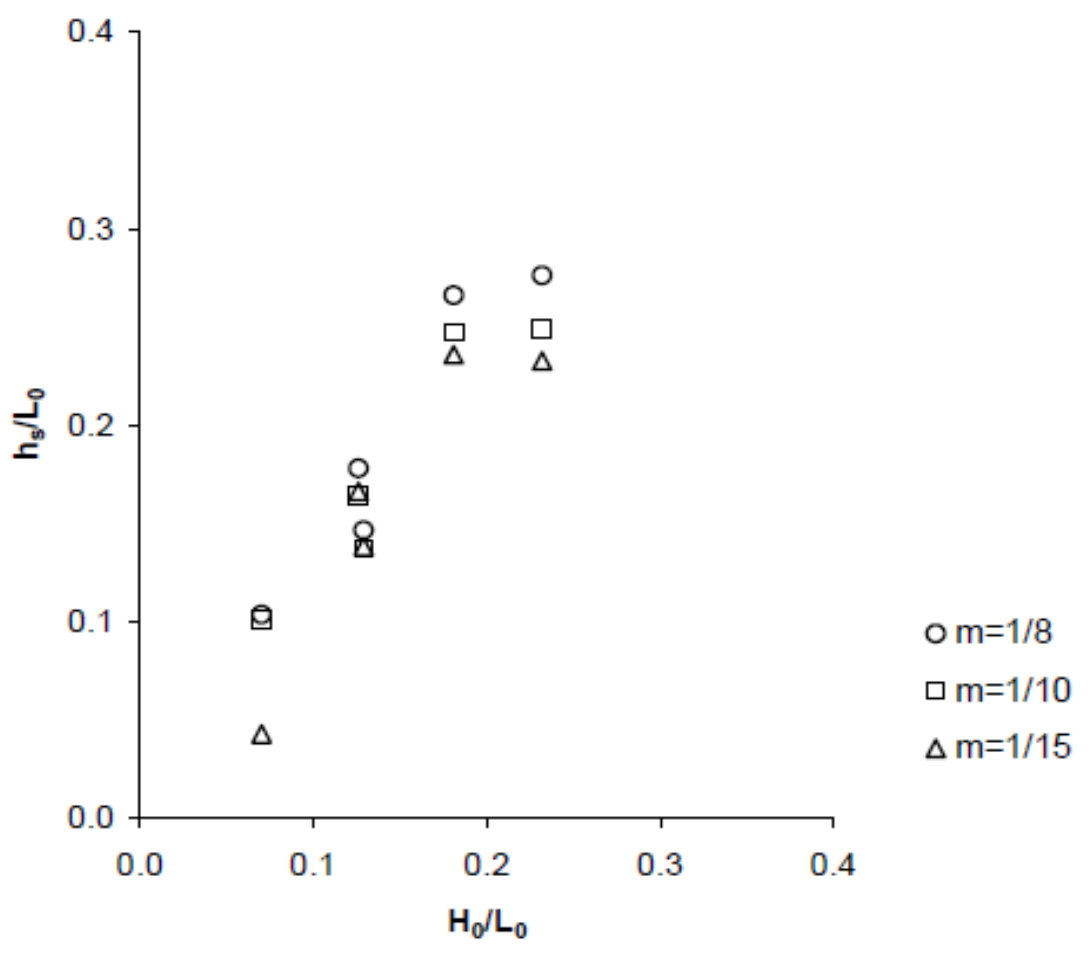

Fig. 7. Variation of Relative Bar Ending Depth with the Wave Steepness for $d_{50}=0.25 \mathrm{~mm}$ 


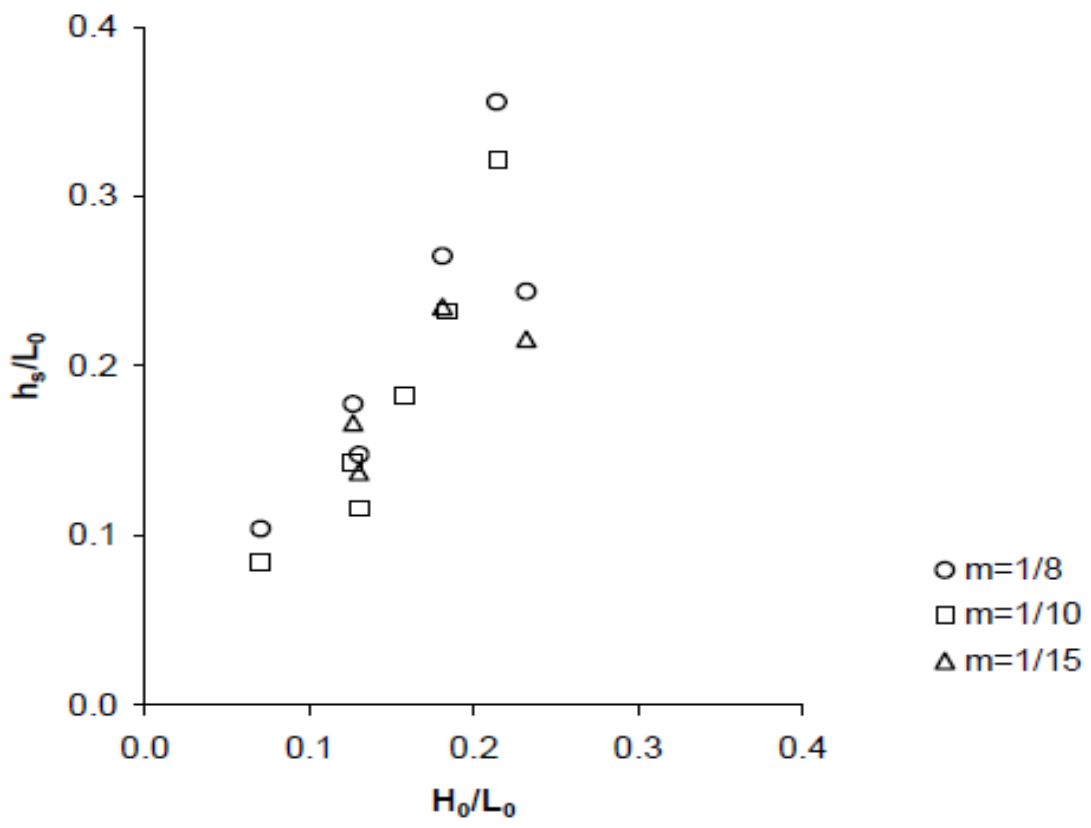

Fig. 8. Variation of Relative Bar Ending Depth with the Wave Steepness for $d_{50}=0.32 \mathrm{~mm}$

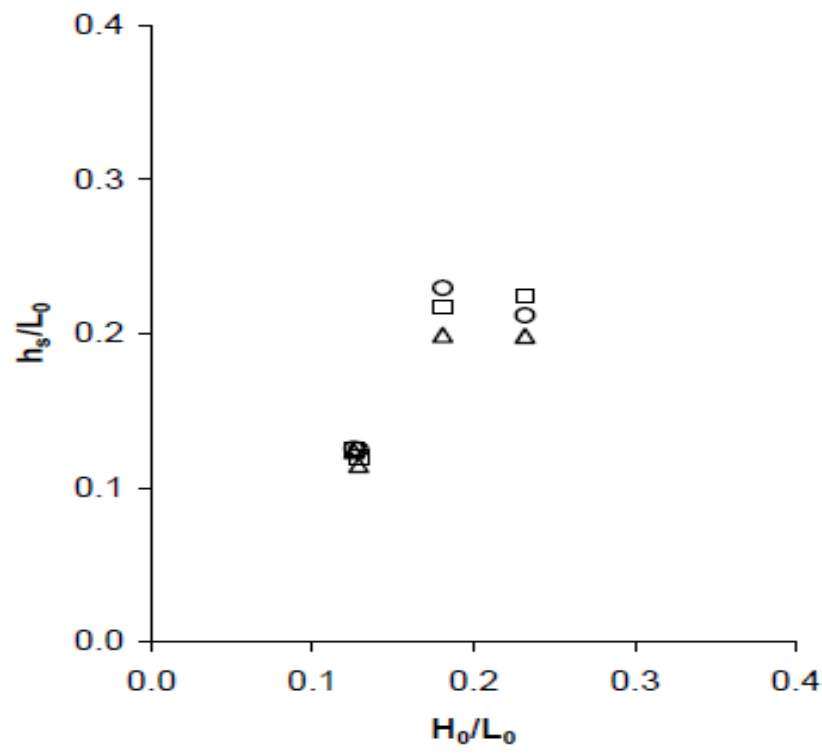

$O m=1 / 8$

$\square \mathrm{m}=1 / 10$

$\Delta m=1 / 15$

Fig. 9. Variation of Relative Bar Ending Depth with the Wave Steepness for $d_{50}=0.45 \mathrm{~mm}$ 


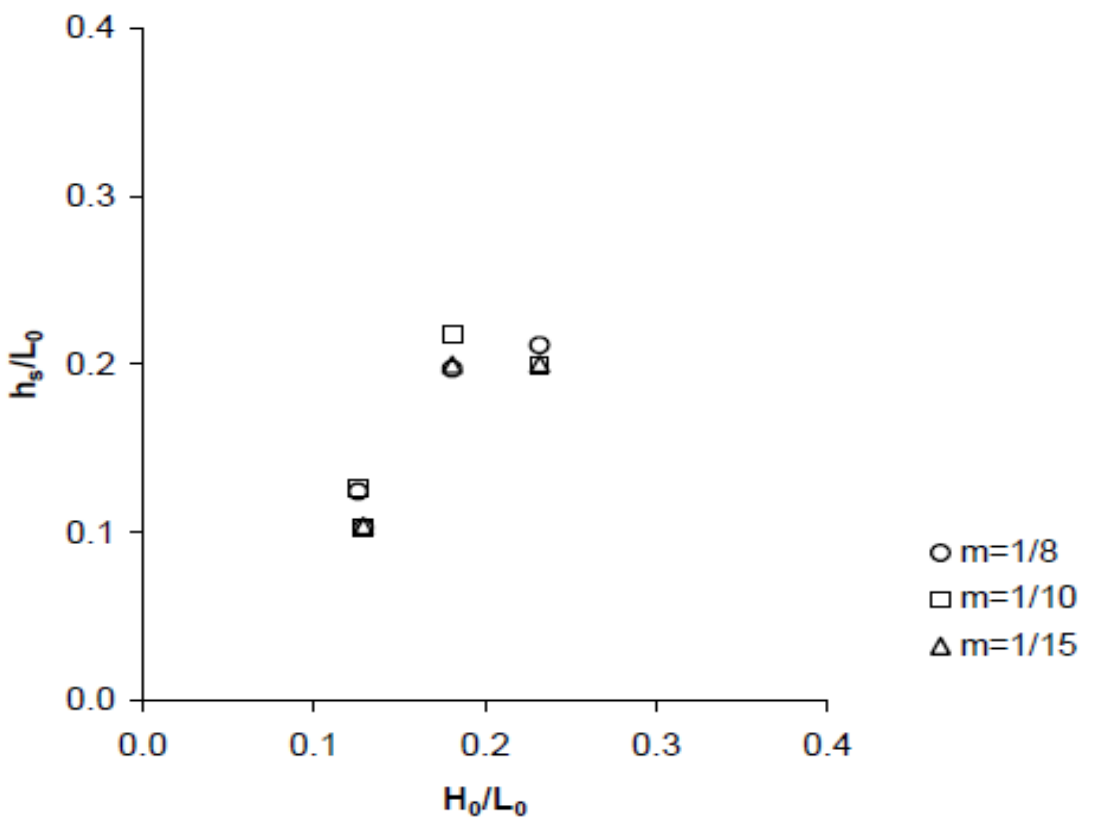

Fig. 10. Variation of Relative Bar Ending Depth with the Wave Steepness for $d_{50}=0.62 \mathrm{~mm}$

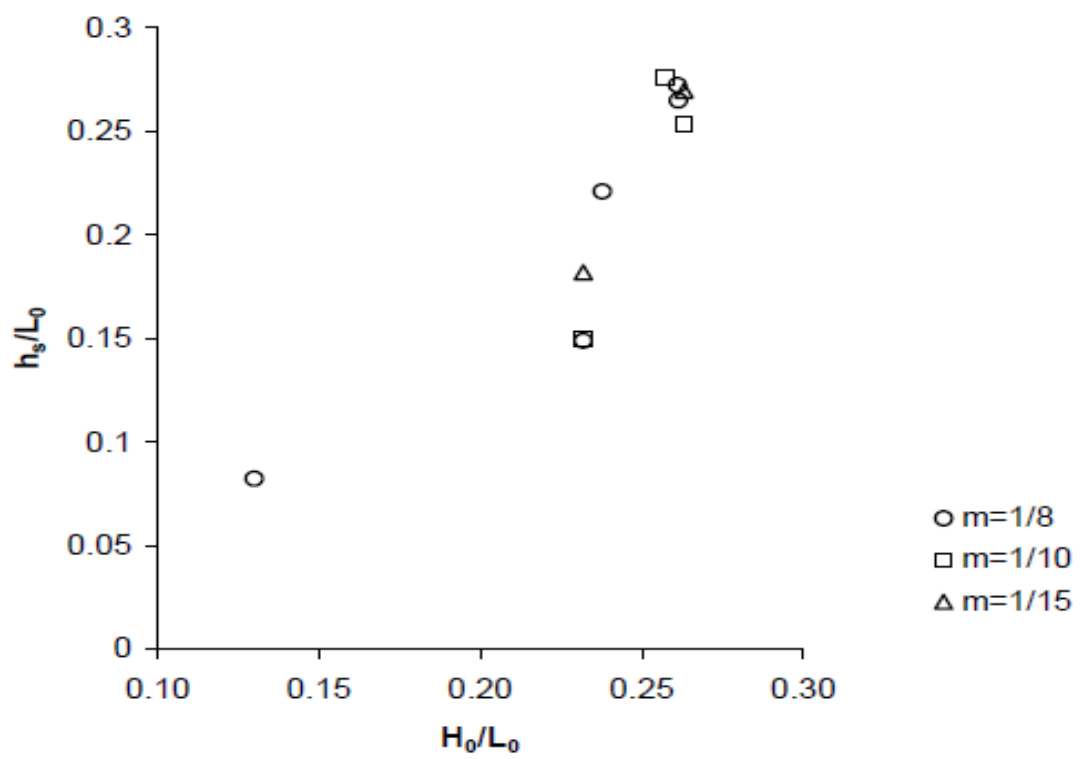

Fig. 11. Variation of Relative Bar Ending Depth with the Wave Steepness for $d_{50}=0.80 \mathrm{~mm}$ 


\section{CONCLUSIONS}

The sediment transport in the perpendicular direction of the shore slopes on the coastal slopes of $1 / 8,1 / 0$ and $1 / 15$ modeled in the wave channel of the Civil Engineering Laboratory and sandbar beginning and ending depths were investigated.

In the experiments carried out under storm conditions, sand material having five different average grain diameters, $\mathrm{d}_{50}=0.25,0.32,0.45,0.62$ and $0.80 \mathrm{~mm}$ was used as the base material.

As a result, as the deep-water wave steepness increases, the net transport to the sea side increases, so the volume of the bar formed on the sea side increases.

With the increasing $\mathrm{H}_{0} / \mathrm{L}_{0}$ values, the bars are moved towards the open, so that the distance of the bar beginning and ending points from the still water level increases.

When the behavior of the material having the same average grain diameter on different base slopes is examined, it is possible to say that with the decrease in base slope, there is generally an increase in the bar beginning and ending depths

\section{REFERENCES}

1. Çelikoğlu Y., Yüksel Y., Kabdaşl1 M. S. (2004), Longshore sorting on a beach under wave action, Ocean Engineering 31, 1351-1375.

2. Çelikoğlu, Y., Yüksel, Y., \& Kabdaşli, M. S. (2006). Cross-shore sorting on a beach under wave action. Journal of Coastal Research, 487-501.

3. Demirci M. (2006). Experimental investigation of cross-shore profile changes. $\mathrm{PhD}$. CU Natural and Applied Sciences Institute, Adana (in Turkish).

4. Demirci M., Aköz M. S. (2012). An investigation on the formation of submerged bar under surges in sandy coastal region. China Ocean Engineering 26(3), 535546.

5. Demirci M., Aköz M. S. (2013). Investigation of bar parameters occurred by cross-shore sediment transport. International Journal of Naval Architecture and Ocean Engineering 5(2), 277-286.

6. Demirci M., Aköz, M. S., Üneş, F. (2014). Experimental investigation of crossshore sandbar volumes. Journal of Coastal Conservation 18(1), 11-16.

7. Demirci M., Üneş, F., \& Aköz, M. S. (2015). Prediction of cross-shore sandbar volumes using neural network approach. Journal of Marine Science and Technology 20(1), 171-179.

8. Demirci M., Unes F., Akoz M. S. (2016). Determination of nearshore sandbar crest depth using neural network approach. International Journal of Advanced Engineering Research and Science 3(12), 133-140.

9. Eichentopf, S., Cáceres, I., \& Alsina, J. M. (2018). Breaker bar morphodynamics under erosive and accretive wave conditions in large-scale experiments. Coastal Engineering, 138, 36-48.

10. Günaydın K., Kabdaşlı M. S. (2005). Investigation of offshore bar geometry under regular and irregular waves. Journal of Coastal Research, 374-382. 
11. Günaydın K., Kabdaşlı M. S. (2003). Characteristics of coastal erosion geometry under regular and irregular waves. Ocean Engineering 30(13), 1579-1593.

12. Hsu T. W. (1998). Geometric characteristics of storm-beach profiles caused by inclined waves. Ocean Engineering 25(1), 69-84.

13. Kankal, M., Uzlu, E., Nacar, S., \& Yüksek, Ö. (2018). Predicting temporal rate coefficient of bar volume using hybrid artificial intelligence approaches. Journal of Marine Science and Technology, 23(3), 596-604.

14. Kömürcü M. İ., Özölçer İ. H., Yüksek Ö., Karasu, S. (2007). Determination of bar parameters caused by cross-shore sediment movement. Ocean engineering 34(56), 685-695.

15. Kraus N. C., Larson, M., Kriebel, D. L. (1991). Evaluation of beach erosion and accretion predictors. In Coastal Sediments (pp. 572-587). ASCE.

16. Larson M., Kraus N. C. (1989). SBEACH: numerical model for simulating storminduced beach change. Report 1. Empirical foundation and model development (No. CERC-TR-89-9). Coastal Engineering research center Vicksburg Ms.

17. Silvester R., Hsu J. R. (1997). Coastal Stabilization. Advanced Series on Ocean Engineering, Vol. 14.

18. Tătui, F., Vespremeanu-Stroe, A., \& Ruessink, G. B. (2016). Alongshore variability of cross-shore bar behavior on a nontidal beach. Earth Surface Processes and Landforms, 41(14), 2085-2097.

19. Türker, U. (2002). Beach Profile Response Analysis Durng Storm Waves (Doctoral dissertation). 